\title{
SPECIAL OPERATIONS FORCES IN UNITED NATIONS PEACE KEEPING OPERATIONS
}

\author{
Octavian DACIN, \\ Colonel (Ret.), MA in Security and Defense, Military Academy of Armed Forces \\ "Alexandru cel Bun", Chisinau, Republic of Moldova. \\ E-mail: dacinoctavian@gmail.com
}

\begin{abstract}
Special Operation Forces had started to participate in the United Nations peacekeeping operations not long ago, but the consensus on acceptability of their use in peacekeeping operations has already been reached. Present article analyzes views on SOF use in peacekeeping, as expressed by the specialist and enshrined in guidance documents of different countries, explores normative regulation formalized in mandates of respective peacekeeping operations and contemplates typical SOF tasks in peacekeeping operations as defined by the UN in "United Nations Peacekeeping Missions Military Special Forces Manual".
\end{abstract}

Keywords: peacekeeping operations; United Nations Organization; Armed Forces; special operation forces; area of operation; SOF operators.

\section{Introduction}

Offering the widest range of capabilities that have direct applicability in a large number of environments, the Special Operations Forces (SOF) are most often the preferred option of political-military decision-makers. SOF actions differ from the actions of conventional forces due to political risks, mode of action, mode of involvement, independence from their own forces and increased dependence on the information and means of indigenous forces (General Accounting Office /NSIAD-97-85).

The SOF includes in its composition specialized structures, from all services and branches of armed forces, which are organized, equipped and trained to carry out specific missions. The methods of training are specific to perform a wide range of missions, which sometimes include deliberate acceptance of risk or covert missions that are part of the range of operations executed by conventional forces.

The participation of special operations subdivisions in peacekeeping operations is a relatively recent practice. For the first time, the SOF were used in peacekeeping operations under the scenario proposed by the UN Secretary-General Dag Hammarskjold, which implied refraining from intervening in the internal affairs of the host countries, not using forces other than those for self-defense, and maximum transparency of the peacekeepers' actions. As the current North Atlantic Treaty doctrine states, the characteristics of the SOF require a wide range of significant applications in peacekeeping operations, but their open use in an unstable political environment can lead to emotional reactions (Allied Joint Publication 3.4.1., 2001). Traditional peacekeeping operations did not imply the involuntary appearance of missions commonly associated with those of the SOF (reconnaissance, destruction/capture of objectives behind enemy lines, organization of partisan movements, training of host units and so on), during the conduct of the service by peacekeepers, so the issue of the admissibility of SOF's participation in peacekeeping operations was not current at the moment. 


\section{SOF operators' competences in peacekeeping operations}

With the end of the Cold War, SOF's participation in peacekeeping operations and other types of multinational operations intensified. As David S. Maxwell wrote in 1995, U.S. special operations forces in one form or another participated in the main UN operations of that time, such as: in northern Iraq, Somalia, Rwanda, Cambodia and Haiti, but in each individual case they were applied differently. In Iraq, they were initially used to assess the area of operations and prepare the entry of following forces, then as a result - as a subordinate task force, to coordinate interaction with the civilian population in the area of responsibility, in a similar way as conventional peacekeepers. In Somalia, they ensured the safety of air transportation with humanitarian aid, then carried out the safety of communication and interaction with the UN forces through the "coalition support groups", organized interaction with the civilian population in the area and finally took part in hostilities. In Haiti, they trained UN forces units, delegated from its composition "coalition support groups", organized information programs and interaction with the civilian population in remote areas (Maxwell 1995). SOF played an important role in NATO operations in Bosnia. They delegated coordination and liaison teams to the staff of all non-NATO units to support and maintain compatibility with the multinational division's staff in ensuring communications, reconnaissance, fire support and evacuation of the wounded. SOF operators provided aid in EOD operations, acted as observers of joint committees, and carried out reconnaissance missions in the interest of the command in the area of responsibility (Bohle 1997, 17). In all these operations, SOF operators did not wear blue helmets, were not included in the composition of the UN peacekeeping contingents, did not hold the status of UN peace maintainers and did not act according to the legal-international framework governing UN peacekeeping operations.

In the literature of the 90's, emphasis is made on the possibility of SOF's participation in UN operations, not on their ability to carry out special reconnaissance and conduct combat operations, but by applying their skills in traditional peacekeeping missions. Thus, Franklin C. Bohle and David S. Maxwell define a series of competences of SOF operators: maturity and experience (Bohle 1997, 4), knowledge of foreign languages, cultural sensitivity, capacities in obtaining information, ensuring the access of Allied forces to communications, intelligence and fire support through "coalition support groups" (Bohle 1997, 35). From the above we can conclude, that SOF operators can carry out missions to obtain information, ensure interaction between multinational forces, train local forces to ensure security and carry out high-precision strikes in favor of the peacekeeping forces command (Bohle 1997, 15).

SOF`s operator deep knowledge of regional culture and foreign languages, as well as the presence of experience of interaction with local forces, are stipulated in the U.S. Armed Forces leadership documents on peacekeeping operations - JP 3-07.3 (Joint Publication 3-07.3. 2018). In the previous version of this document, were established missions for special operations forces in the peacekeeping operations of the United States, such as: carrying out psychological operations; collection of information; ensuring the detailed assessment of specific areas; interaction with the Armed Forces and the local civilian population, with other peacekeeping contingents and agencies; training and organization of security forces; use of aircraft and helicopters (Joint Publication 3-07.3. 2018, II-9). According to NATO's peacekeeping doctrine, the ability of SOF operators to cover large areas in secret, with secure communication, allows them to act quickly, immediately after the establishment of liaison, recognition and other missions. SOF operators can also organize civil-military interaction with the local population, ethnic communities in the area, to inform them and also train and reform local security forces (Allied Joint Publication 3.4.1. 2001, 5-7).

The basic document governing the activities of the British Armed Forces in the field of peacekeeping operations is AJP-3.4.1(A) The Military Contribution to Peace Support 
STRATEGIES XXI International Scientific Conference

The Complex and Dynamic Nature of the Security Environment

Operations. The three basic missions of the SOF: observing and reconnaissance; offensive operations (to achieve the calculated and precisely concentrated effect, physical or psychological, with minimum damage); support and influence (including the preparation of 'third parties' and/or the provision of influence over them; the "mastery of the minds and hearts" of the native population, influencing it, through information operations), can be carried out both in peacetime and in wartime, or during a conflict, together or separately. This category also includes any other missions that contribute to implementing the operational plan of the peacekeeping forces command, such as: the completion of civil-military projects and the fulfillment of the duties of military observers in conditions of high-tension situation (Maxwell, 1995, 5-21).

Western experts are not alone in their view of the opportunity of SOF operators' participation in peacekeeping operations. In 2000, specialists from the Russian Federation already included reconnaissance missions for special operations in peacekeeping operations and medical humanitarian aid operations, without detailing the missions during such participation (Freze 2000, 4).

\section{SOF operators' application in peacekeeping operations}

Taking into account the above, we can divide two approaches to the application of SOF in peacekeeping operations:

- "Moderate", suggesting the use in peacekeeping operations of the skills characteristic to SOF operators without changing the essence of peacekeeping operations (US, NATO).

- "Radical", involving a change in the essence of peacekeeping operations under the aegis of the UN: the acceptance of covert actions and the extensive use of force, which will make it possible to apply the combat skills of SOF operators on a large scale (UK).

- What approach is typical for peacekeeping operations under the United Nations aegis? Existing trends allow us to state that peacekeeping operations under the UN aegis are typically the second option, the "radical" one, because several changes are observed in the conduct of peacekeeping operations, namely:

- the expansion of missions (from the maintaining the traditional peace to maintaining a multidimensional peace);

- expanding cases of the use of force and an increase in the level of force applied (from self-defense to defending the mandate, from maintaining traditional peacekeeping to robust peace enforcement).

The works cited above, written by Franklin C. Bohle and David S. Maxwell in 19951997, did not describe the combat experience of the UN`s "blue helmets". Meanwhile, the changes in the 2000s necessitated radical changes in the use of peacekeeping forces, which were completely unimaginable at the time of the " Agenda for Peace "drafting. These changes also found room for special operations forces in the UN peacekeeping contingents.

The first case of the application of SOF operators as part of the UN peacekeeping force (and not interacting with "blue helmets") took place in Burundi. In his resolution of 16 March 2004, the UN Secretary-General defined that it is necessary to include SOF operators in the peacekeeping contingent for the successful completion of the mission (First report of the Secretary-General on the United Nations Operation in Burundi S/2004/682). For setting up the UN peacekeeping operation in Burundi (hereinafter - ONUB), troops from the African Union mission in Burundi (hereinafter - AMIB) were deployed, which included South African SOF operators. South Africa agreed to send them to the ONUB until their replacement arrived (Overview of Secretary-General's Reports, S/2004/210). SOF operators also participated in the UN peacekeeping mission in Darfur, 31 July 2007 (hereinafter - UNAMID). SOF operators in 
Nepal characterized themselves as "a vital element, allowing reserve forces to respond quickly to the mission threats." (Resolution 1769 2007).

The next additional step in the development of the practice of applying SOF operators in UN peacekeeping operations became a mission in Congo (hereinafter - MONUC, then reformed in MONUSCO). The commander of the MONUC mission P. Cammaert thus characterized the features of this mission. For the first time in the history of MONUC peacekeeping UN aegis formed... plus an enormous number of helicopters, impressive engineering capabilities and special operations forces for conducting military action in accordance with Chapter VII (UN Charter 1945) problematic region of the Republic of Congo. This represents a global change in peacekeeping, as a result of which the UN receives adequate military means for the execution of a mandate of coercion with strict rules for the use of force, which implies a more aggressive position of UN troops and a higher tempo of use, which sometimes leads to a deadly character (CAMMAERT 2010). The Special Operations Forces were an integral element of the UN strategy in Congo that used them without hesitation.

The actions of MONUC SOF operators differed drastically from the usual way of UN peacekeepers action. On January 18, 2006, MONUC dispatched its SOF operators from Guatemala to Garamba National Park, receiving information about the alleged presence of militants from the "Liberation Army of the Lord", including commander V. Otti, whose arrest warrant was issued by the International Criminal Court. On $23^{\text {rd }}$ of January, as they approached the militants' camp, MONUC SOF operators came under their fire, as a result of which eight peacekeepers were killed and five were injured (Joint Publication 3-07.3. 1999, 8). That situation provoked drastic debates about how much the international community is willing to go with military methods, in order to maintain peace in the DR Congo ().

The failure described above did not result in the termination of the use of SOF operators by the UN in Congo. On the contrary, this failure led to the adoption of the UN Security Council resolutions 2098 (2013) of 28 March 2013, for their use. According to this resolution, the UN Security Council established a "Task Force" as part of the UN Stabilization Mission in Congo (MONUSCO), the component of which included a reconnaissance company and a special operations company. This brigade was intended to neutralize militant groups and had a mandate to: "conduct offensive operations in a harsh, highly mobile and diverse environment, in strict accordance with the standards of international law, including international humanitarian law and the UN human rights audit policy in support of non-UN formations, prevent the expansion of all armed groups, neutralize the expansion of all military groups, to reduce the threat they pose to state power, to ensure stabilization of activities and civilian security in western areas of the DRC"1.

Resolution 2098 (2013) played a critical role, both in the practice of UN peacekeeping operations and in the practice of using SOF operators in them. This resolution provides for UN peacekeepers, in general, and SOF operators, in particular, the greatest freedom at the moment for the use of force. Sometimes the peacekeepers acted in this way, but their aggressiveness in actions was never dealt at the level of the mission's mandate - its fundamental document. Most of the legal-international impacts on the use of SOF operators in combat and reconnaissance operations were removed, and the remaining restrictions relate to how combat operations are conducted. From the above, we conclude that Resolution 2098 (2013) provided these changes in duties only for the operators in the SOF company, as part of the "Operative Intervention Brigade". For the other SOF operators in the composition of the MONUSCO forces, the attributions remained unchanged, according to the contingent mission (Security Council SC/10964, 2013).

1 A.N.: Search engine for the United Nations Security Council Resolutions, S/RES/2098, URL: http://unscr.com/en/resolutions/2098 
STRATEGIES XXI International Scientific Conference

The Complex and Dynamic Nature of the Security Environment

Another mission of the UN peacekeeping contingent with the participation of Dutch SOF operators was the United Nations integrated mission on stabilizing the situation in Mali (hereinafter - MINUSMA). Mandate 2100 (2013) MINUSMA of 20 April 2013 put before the peacekeepers the mission "in support of the transition authorities in Mali to provide stabilization of the situation in the main localities in the region, especially in northern Mali and as a result to repel threats and take active measures to prevent the return of militant elements to these areas, which allows UN peacekeepers the option to take preventive-active actions (Security Council resolution 2100, 2013).

As the situation in Mali got complicated day by day, proposals were put forward to reform the MINUSMA mission. According to the vision of the MINUSMA mission commander, the contingent of UN peacekeepers, who should act in establishing and maintaining peace, was confronted with the activities of terrorist networks in the region and fought against them, without having the proper mandate, the necessary training, equipment, logistical provision and intelligence. ${ }^{2}$ Mali's foreign minister proposed to the Security Council "within a time-frame as soon as possible to review the mandate of MINUSMA and strengthen their capacity and resources so that they can cope with the outbreak of violence in the country... " Perhaps the Council should review the question of the establishment of 'Operational Reaction Forces', which maintain a potential to fight terrorists. ${ }^{3}$ There is no doubt that the change of MINUSMA's mandate to one for the fight against terrorism would imply more operational freedom for its contingent of SOF operators.

The situation in the area of responsibility of the UN integrated mission to the Central African Republic (hereinafter - MINUSCA) looked not so sad, but the mission required the involvement of SOF operators (Security Council 2014). The mandate of S/RES/2149 (2014), MINUSCA, of 10 April 2014 provided the mission "to ensure, within the limits of its capabilities and the areas of deployment, including active patrolling, the protection of the civilian population against physical violence." "As a result, we can see that even the harshest wording of the mandate would not bring a positive result, if the mission staff would not be active in the execution of such mandate.

In the absence of detailed regulation of the SOF operators use in UN peacekeeping operations, their missions are described in detail in the "Handbook on Special Operations Forces for UN Peacekeeping Missions" issued by the Department of Peacekeeping Operations and the Field Support Department. It provides a definition for the concept of UN Special Operations: "military actions carried out by special formations, organized, trained and equipped decently, supplemented with selected personnel, using unconventional tactics, techniques and methods of action. These actions may be carried out within the framework of a wide range of UN peacekeeping operations, in accordance with the principles and spirit of peacemaker, and in the context of the mission's mandate ". ${ }^{5} \mathrm{UN}$ special operations can be carried out at different stages of the mission: at the initial stage, while SOF operators can achieve favorable conditions for the full deployment of the mission, stabilization and protection of the civilian population, and finally, during peace-building, when they can ensure advanced training and the development of opportunities for the armed forces of the host country.

\footnotetext{
2 A.N.: This was a meeting on the report of the Secretary-General on the situation in Mali, S/PV.7274, URL: https://www.securitycouncilreport.org/un-documents/document/spv7274.php

${ }^{3}$ A.N.: This was a briefing on peacekeeping operations by force commanders from MONUSCO, MINUSMA and UNDOF, S/PV.7275, URL: https://www.securitycouncilreport.org/un-documents/document/spv7275.php

${ }^{4}$ Letter dated 29 January 2015 from the Secretary-General addressed to the President of the Security Council, S/2015/85, https://undocs.org/S/2015/85

5 United Nations Peacekeeping Missions Military Special Forces Manual // DPKO - DFS, January 2015, http://www.enopu.edu.uy/wp-content/uploads/manual-UNMUM-Special-Forces-2015.pdf, p.9.
} 
One of the criteria for establishing the missions for UN SOF operators is the compliance of these missions with the mandate and legal framework of the UN operation, including the rules of engagement. Particularly, the rules regarding using force must be formulated taking into account the specific missions of UN SOF operators. ${ }^{6}$

\section{UN SOF operators' basic missions}

Special Surveillance and Reconnaissance $(S R)$ - they complement the effort and the system of collecting information at national level and the theaters of operations, by obtaining significant, specific, very well defined and time-bound data and information at the strategic and operational level. Surveillance and reconnaissance missions can complement other collection methods, when there are certain constraints dictated by weather conditions, difficult terrain, hostile countermeasures, etc. Special surveillance and reconnaissance is a predominant function of Human Intelligence (HUMINT), which has the ability to place "eyes on the target" in a hostile, forbidden or politically sensitive territory. The Special Operations Forces can provide timely analysis by using the initiative and their own method of evaluation in a way that other technical procedures are not possible. They can carry out these missions independently, supported or in conjunction with/for the benefit of other categories of forces/component commands and can use reconnaissance and surveillance techniques, advanced equipment and methods to collect data and information, sometimes supplemented by indigenous means.

SR specific activities include the following:

- Environmental Reconnaissance These are operations carried out for the collection and reporting of critical geospatial data and information, including hydrographic, geological, geographical and meteorological.

- Threat assessment. Threat assessment should be based on accurate and timely information whenever possible.

- Specific Assessment. These are operations carried out to detect, identify, locate and assess a target, in order to determine the greatest efficiency in the use of different weapon systems. This type of operation may also include assessing the potential effects (including collateral damage) of the target's engagement. ${ }^{7}$

Direct Actions (DA) are high-precision operations, limited in purpose and duration. Direct actions normally involve a planned withdrawal from the area in the immediate vicinity of the objective; focus on specific, well-defined targets of strategic or operational value or in the context of decisive tactical operations. Special Operations Forces can conduct these types of missions independently or with the support of conventional forces.

Direct actions include the following:

- Raids, ambushes, direct assaults. These operations are intended to achieve specific, well-defined and often time-sensitive results. They are sometimes beyond the actual capabilities of hitting elements of conventional forces. Such operations typically involve attacking critical targets, disorganizing the Lines of Communications (LOC), capturing personnel, models of military equipment and armaments, conquering, destroying/neutralizing enemy capabilities or facilities.

- Routing operations for the target engagement. These are operations carried out to identify and report the precise location of target to enable non-organic SOF platforms to use high-precision weapon systems. This includes any type of electronic, mechanical or voice

\footnotetext{
${ }^{6}$ Ibidem, p. 14.

7 United Nations Peacekeeping Missions Military Special Forces Manual // DPKO - DFS, January 2015, http://www.enopu.edu.uy/wp-content/uploads/manual-UNMUM-Special-Forces-2015.pdf, p.17.
} 
STRATEGIES XXI International Scientific Conference

The Complex and Dynamic Nature of the Security Environment

communication, which provides the aircraft/weapon system to be used with additional information about the specific location of a target.

- Personnel recovery operations. These are operations performed to search, locate, rescue and bring back to your own personnel, sensitive equipment, or critical elements for the security of a state in combat areas or areas controlled by the enemy. SOF recovery missions are characterized by detailed planning, numerous rehearsals and a thorough informative analysis. These types of operations use unconventional tactics and techniques, a discreet crawl and the frequent use of ground teams.

- Precision damage are operations in which collateral damage must be minimized. In this type of operations, highly sophisticated precision weapons or the scheduled initiation of specific quantities and types of explosive substances are used, located in exact locations to achieve the mission's objectives. Precision destruction operations can be carried out against targets on which weapon systems using high-precision guided ammunition do not guarantee success from the first hit, or when what contains a particular facility must be destroyed without causing damage to the entire facility. ${ }^{8}$

Military assistance (MA) is a broad set of measures in support of friendly forces throughout the conflict spectrum. Military assistance may be carried out by, with or through friendly forces that are trained, equipped, supported or used to a varying extent by the SOF. The extent of military assistance is considerable and can range from the provision of military training to material support for the engagement of indigenous forces active in major operations, if the mission's mandate also allows for consideration of UN human rights audit policy. Military assistance activities may include the following:

- Training. This represents a complex of activities of training the soldiers and units of the host nation Armed Forces in the use at the tactical level, of supporting and integrating the combat skills; provides specific advice, assistance and training to military leaders in the use of tactics, techniques and techniques to strengthen the host nation's potential to protect itself against threats and to develop the necessary individual and organizational skills.

- Counseling. These are activities that strengthen the security of the population by offering an active participation in tactical level operations carried out by the host nation military units with the aim of neutralizing insurgent threats, isolating the insurgents from the civilian population and protecting it (United Nations 2015).

\section{Conclusions}

From the above we can conclude that:

- SOF operators have gone a route from unimaginable to the need to include them as an essential component of the United Nations peacekeeping contingents. The UN Security Council supports the practice of using SOF operators in peacekeeping operations by approving the relevant reports of the Secretary-General and, in the case of Resolution 2098 (2013), directly supporting the inclusion of SOF operators in the "Operational Intervention Brigade" component of the MONUSCO mission. Expanding the range of action of peacekeepers and the legal cases of the use of their force, provides more and more opportunities to use the specific skills of SOF operators. The current trend gives reason to an increase in the participation of SOF operators in peacekeeping operations.

- The mandates of the MISSIONS ONUB, UNAMID, MINUSCA, MINUSMA and MONUSCO differ from each other, but SOF operators are an important component of each of these missions. Most UN special operations can be carried out within the framework of each

\footnotetext{
${ }^{8}$ Ibidem, p.18.
} 
mandate of current UN missions along with an armed contingent of peacekeepers. The specific wording of the mandate (e.g. MONUSCO's mandate) may "untie loose hands" in the actions of SOF operators, but it is not a mandatory condition for their use in the appropriate missions.

- The use of UN SOF operators requires some standardization of use, legal explanations, or a concept of their alternative status to be presented, which would provide, on the one hand, the UN with an instrument of power and, on the other hand, non-involvement of the "ordinary" peacekeeping staff in the conflict.

\section{BIBLIOGRAPHY:}

North Atlantic Treaty Organization. 2001. Allied Joint Publication 3.4.1. Peace Support Operations.

BOHLE, Franklin C. 1997. Army Special Forces: a Good Fit for Peace Operations / Franklin C. Bohle // United States Army War College. - Carlisle Barracks, Pennsylvania, ASIN: B0006QP4MC.

CAMMAERT, Patrick, major-general, Former UN Military Adviser and former Division Commander, MONUC, URL: https://www.ipinst.org/images/pdfs/favoritapaper/ favoritacammaert.pdf

United Nations. 1945. Charter of the United Nations, URL: http://www.oas.org/XXXIVGA/ English/reference_docs/Carta_NU.pdf

United Nations Security Council. 2004. First report of the Secretary-General on the United Nations Operation in Burundi S/2004/682. URL: https://undocs.org/ru/S/2004/682

General Accounting Office. NSIAD-97-85 Special Operations Forces - Opportunities to Preclude Overuse and Misuse.

Reliefweb. 2006. Guatemalan Blue Helmet Deaths Stir Congo Debate. URL: https://reliefweb.int/report/democratic-republic-congo/guatemalan-blue-helmet-deathsstir-congo-debate

United States Joint Chiefs of Staff. 1999. Joint Publication 3-07.3. Peace Operations.

United States Joint Chiefs of Staff. 2018. Joint Publication 3-07.3. Peace Operations.

Joint Doctrine \& Concepts Centre. 2004. Joint Warfare Publication 3-50. The Military Contribution to Peace Support Operations.

United Nations Security Council. 2015. Letter dated 29 January from the Secretary-General addressed to the President of the Security Council, S/2015/85, https://undocs.org/S/2015/85.

MAXWELL, David S. 1995. Support to United Nations Operations: Is There a Role for United States Special Operations Forces, School of Advanced Military Studies, United States Army Command and General Staff College, Fort Leavenworth, Kansas, First Term AY 95-96.

Security Council. 2004. Overview of Secretary-General's Reports, S/2004/210, URL: https://www.securitycouncilreport.org/un-documents/document/burundi-s2004210.php

Security Council. Overview of Security Council Meeting Records, S/PV.5784, URL: https://www.securitycouncilreport.org/un-documents/document/sudan-spv5784.php

Security Council. 2006. Overview of Secretary-General's Reports, S/2006/390. URL: https://www.securitycouncilreport.org/un-documents/document/drc-s2006390.php

Security Council. 2007. Resolution 1769 (2007) / adopted by the Security Council at its 5727th meeting, on 31 July 2007, S/RES/1769 Darfur (UNAMID). URL: https://digitallibrary.un.org/record/604309 
Security Council. 2013. Resolution 2100 [on establishment of the UN Multidimensional Integrated Stabilization Mission in Mali (MINUSMA)]. URL: https://www.refworld.org/docid/519dffbe4.html

Security Council. 2014. Resolution 2149 [on establishment of the UN Multidimensional Integrated Stabilization Mission in the Central African Republic (MINUSCA) until 30 Apr. 2015]. URL: https://www.refworld.org/docid/537c6ea64.html

Security Council. 2013. Security Council SC/10964, Authorized as Security Council Grants Mandate Renewal for United Nations Mission in Democratic Republic of Congo Resolution 2098. URL: https://reliefweb.int/sites/reliefweb.pdf

Security Council. 2014. Meeting on the report of the Secretary-General on the situation in Mali, S/PV.7274. URL: https://www.securitycouncilreport.org/un-documents/document/ spv7274.php

Security Council. 2014. This was a briefing on peacekeeping operations by force commanders from MONUSCO, MINUSMA and UNDOF, S/PV.7275. URL: https://www.security councilreport.org/un-documents/document/spv7275.php

United Nations. 2015. United Nations Peacekeeping Missions Military Special Forces Manual //DPKO - DFS, January 2015. URL: http://www.enopu.edu.uy/wp-content/uploads/ manual-UNMUM-Special-Forces-2015.pdf

FREZE V.R., KUZIN V.N., KOTKOV S.A. 2000. Sputnik razvedchika: [uchebno-metod. posobie], pod red. M.L. Tihomirova-Novosibirsk: Novosibirskij voennyj institut. URL: https://www.twirpx.com/file/1448724 